\title{
TOO OLD AMS RADIOCARBON DATES OBTAINED FROM MOSS REMAINS FROM LAKE KWIECKO BOTTOM SEDIMENTS (N POLAND)
}

\author{
JACEK MADEJA $^{1}$ and DARIUSZ LATOWSKI ${ }^{2}$ \\ ${ }^{I}$ Department of Palaeobotany, Institute of Botany, Jagiellonian University, \\ Lubicz 46, 31-512 Kraków, Poland \\ ${ }^{2}$ Department of Biochemistry, Institute of Biology, Pedagogical University, \\ Podchorązych 2, 30-084 Kraków, Poland
}

Received 15 September 2008

Accepted 30 January 2009

\begin{abstract}
The paper presents the results of the AMS radiocarbon dating of moss macrofossils which seem to be too old in the context of palynological data. The lack of agreement between the obtained results of radiocarbon dating and pollen analysis has been discussed. Some possible causes of the discrepancies between the results of radiocarbon dating and palynological dating have been given.
\end{abstract}

Keywords: AMS radiocarbon dating, old carbon effect, moss remains, Holocene

\section{INTRODUCTION}

Radiocarbon dating based on the ${ }^{14} \mathrm{C}$ isotope is a tool that is frequently used to determine the age and duration of changes taking place in the palaeoenvironment. The remains of terrestrial plants are reliable material for radiocarbon dating, but they are not always present in sediment. Dating the remains of aquatic plants often gives highly skewed results, as does dating the remains of terrestrial plants which are capable of photosynthesis under conditions of episodic flooding, and thus of incorporating into their tissues atoms of carbon dissolved in the surrounding environment.

The introduction of modern accelerator technique (AMS) has made it possible both to date samples which are much smaller than those used in conventional methods and to date new kinds of material which are not available in larger quantities. Dating pollen grains isolated from sediment is particularly important in reconstructing changes taking place in the flora (Brown et al., 1989). This method is most useful in those situations in which sediments contain no macroremains of land plants.

Correlating the radiocarbon age obtained from a profile together with palynological data concerning changes taking place in the flora with data available for other profiles taken from adjacent areas whose dates do not appear dubious allows the former to be critically verified.

This paper presents the results of the radiocarbon dating of moss macrofossils and pollen concentrates. The lack of agreement between the obtained results of radiocarbon dating and pollen analysis has been discussed, and the age of the investigated sediment has been determined by confronting the palynological data with those taken from other, already dated pollen profiles. Some possible causes of the discrepancies between the results of radiocarbon dating and palynological dating have been given.

\section{STUDY SITE}

Lake Kwiecko (54 01'30” N, $16^{\circ} 42^{\prime}$ '00”E) lies in the Bytowskie Lake District which is a part of the West Pomeranian Lake District, Northern Poland (Fig. 1) within the stadial moraines of Late Glacial time (Kondracki, 2002). Lake Kwiecko is located at an elevation of $80 \mathrm{~m}$ a.s.l. and its surface area is approximately $127 \mathrm{ha}$. The lake basin occupies a depression formed in calcareous glaciofluvial gravels. The basement of the Quaternary sediments is composed mainly of Tertiary marine green glauconite sands, sandy loams, silts and Miocene clays, sands and brown coals. 


\section{MATERIALS AND METHODS}

\section{Fossil material}

A core over $22 \mathrm{~m}$ deep was taken using a Więckowski sampler (Więckowski, 1970). Sediment of a gyttja carbonate nature contained distinctly laminated material at a depth of 19.29-21.06 m, and sandy clay at the bottom. There was mossy peat at the depth of 22.08-22.27 $\mathrm{m}$ in the profile, with mainly Drepanocladus aduncus, as well as Calliergon stramineum and Scorpidium scorpioides. The proportions of organic carbon and carbonates were assessed in the profile (Dean, 1974), and palynological investigations were carried out.

\section{Palynology}

Samples for palynological analysis were taken from segments of the core at $5-10 \mathrm{~cm}$ intervals. Samples with Lycopodium tablets were prepared for palynological analysis using the modified Erdtmann's acetolysis method (Stockmarr, 1971; Berglund and RalskaJasiewiczowa, 1986). In each of the samples, 800 grains of tree and shrub pollen were analyzed, together with accompanying grains of herbaceous plants, and spores.

The results of pollen analyses were presented in the form of diagrams made using the POLAPL program (Walanus and Nalepka, 1999). The relative percentages of taxa were determined in relation to the total sum $(\mathrm{AP}+\mathrm{NAP})$, excluding the pollen and spores of local plants.

\section{Radiocarbon dating}

AMS radiocarbon dating was carried out in the Poznań Radiocarbon Laboratory for two types of material, namely the macroremains of the mosses Drepanocladus aduncus and Calliergon stramineum, present only in the bottom part of the profile, and grains of pollen isolated according to the method described by Nakagawa et al. (1998). Calibration of the dates was performed with the help of CALIB Radiocarbon Calibration Program version 5.0.2 (Stuiver and Reimer, 1993; Reimer et al., 2004).

\section{Modern material}

In order to determine whether Drepanocladus aduncus is capable of photosynthesis when submersed, the photosynthetic activity (changes in oxygen concentration and $\mathrm{pH}$ ) of a live specimen of Drepanocladus aduncus was measured using the method described by Bain and Proctor (1980), Allen and Spence (1981) and MacDonald et al. (1987). Leaves cut into pieces were placed inside a reaction chamber filled with $0.2 \mathrm{mM} \mathrm{NaHCO}$ solution as the source of carbonate ions, with an initial $\mathrm{pH}$ of 7.1. The electrode of a $\mathrm{pH}$-meter was placed in the chamber and also Clark's oxygen electrode measuring the amount of evolved oxygen. The reaction mixture was illuminated with light from a source with an effective emitter temperature of $2650^{\circ} \mathrm{K}$. Measurements were made by the equipment developed for real-time simultaneous measurements of $\mathrm{pH}$ using $\mathrm{pH}$-meter Oakton Series pH510 (USA) and oxygen concentration changes in aqueous samples using Clark Electrode HansaTech (UK).

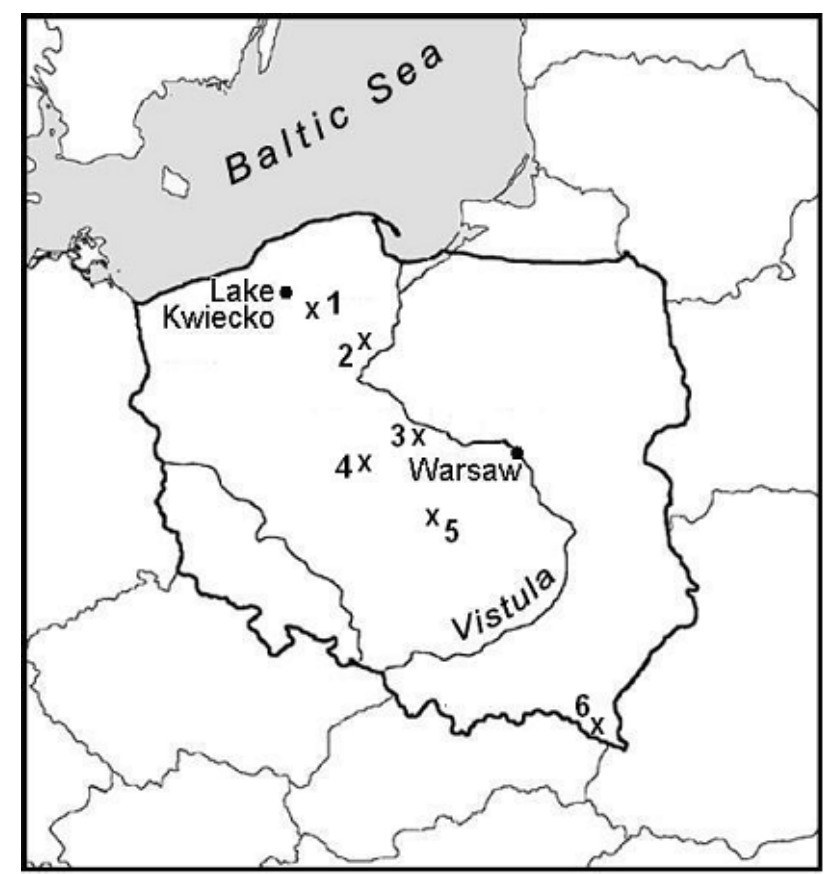

Fig. 1. Localization of Lake Kwiecko and other palynological sites named in the text. 1 - Lake Gacno Wielkie (Hjelmroos-Ericsson, 1981), 2 - Lake Mukrz (Noryśkiewicz, 2006), 3 - Lake Gościąż (RalskaJasiewiczowa et al., 1998), 4 - Maliniec II (Tobolski, 1991), 5 - Lublinek (Balwierz, 1995), 6 - Smerek (Ralska-Jasiewiczowa, 1980).

\section{RESULTS AND DISCUSSION}

\section{Palynology}

The profile spans a continuous record of local changes which took place in the Holocene in the vegetation of the vicinity of Lake Kwiecko. Pollen analysis of the lake's bottom sediments made it possible to determine that sedimentation in its basin had started at the beginning of the Preboreal, when pine-birch forests with a small proportion of Ulmus (Fig. 2) dominated there. The high proportion of tree pollen, up to a maximum of $99 \%$, is evidence of the whole area having been forested. During the boreal period, Corylus became an important element of the pine-birch forests. The Atlantic is characterized by a reduction in the proportion of Pinus and the spread of Ulmus, Quercus, Tilia and Alnus. Hedera helix and Viscum, indicators of a warm climate, were present. At the beginning of the sub-boreal period, the proportion of Ulmus declined, Corylus, Quercus, and Alnus dominating instead. New taxa of trees spread, namely Fagus and Carpinus. During the sub-Atlantic the proportion of $\mathrm{Fa}$ gus and Carpinus increased. At the top of this chronozone the area becomes much more open and herbaceous plants spread, these including palynological indicators of human activity. The course of pollen curves does not show a possible break in sedimentation at any point in the profile.

A similar palynological picture of vegetation transformation at the beginning of the Holocene is known from other pollen diagrams whose chronology has been examined in detail and from isopollen maps for Poland. 


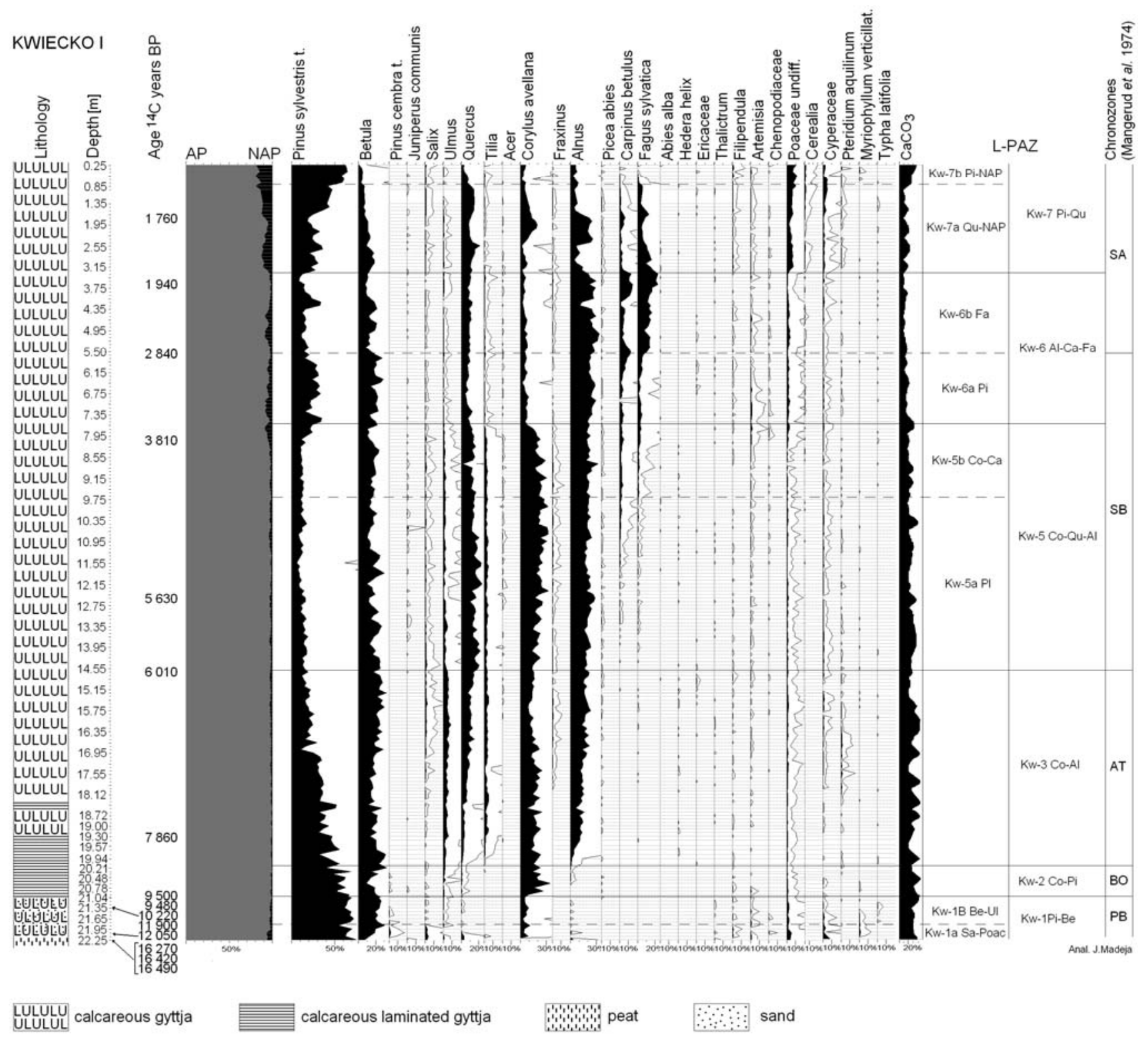

Fig. 2. Lake Kwiecko - abridged pollen diagram.

The results of radiocarbon dating obtained for moss remains $\left(16,270 \pm 230,16,420 \pm 100\right.$ and $\left.16,490 \pm 170{ }^{14} \mathrm{C} \mathrm{BP}\right)$ (Table 1) are undoubtedly aged and are not supported by the palynological data. Pollen grains of Ulmus, Quercus, and Alnus are present in the Preboreal identified in the pollen diagram from Lake Kwiecko, much as in analogous chronozones identified in a pollen diagram from Lake Gacno Wielkie (Hjelmroos-Ericsson 1981), $70 \mathrm{~km}$ from Lake Kwiecko, and from Lake Gościąż (RalskaJasiewiczowa et al., 1998) $250 \mathrm{~km}$ away (Fig. 1).

On the basis of AMS radiocarbon dating, the section discussed should be associated with the upper Plenivistulian. The pollen spectra recorded in sediments of this period suggest the existence of sparse pioneer vegetation of the steppe tundra type with occasional trees, which is associated with conditions of climate that are not conducive to the development of richer communities (Mamakowa, 2003; Balwierz, 2003). Before the encroachment of the glacier the climate varied along a north-south axis, from high arctic in the north, midarctic in central Poland, to subarctic-boreal in the southern part of the country. Whereas in the southern part of Poland forest tundra communities of the park type with Larix, Pinus cembra and Betula (Mamakowa and Starkel, 1977) may have persisted, localities from Central Poland (such as Maliniec II; Tobolski, 1991) indicate the dominance of open tundra communities with a NAP pollen component of above $90 \%$.

Palynological data spanning the period during which the ice sheet receded, from the Smerek locality in the Bieszczady Mountains in southern Poland (RalskaJasiewiczowa, 1980) indicate the existence of a refuge of open forest with Larix and Pinus cembra. Meanwhile, pollen analysis carried out for two localities from central Poland (namely Lublinek-station 1, dated at $17,100 \pm 200{ }^{14} \mathrm{C} \mathrm{BP}$ and Lublinek-station $\mathrm{b}$ dated at $16,200 \pm 200{ }^{14} \mathrm{C} \mathrm{BP}$ ) points to the existence of very poor, discontinuous sedge and moss communities of a pioneer type (Balwierz, 2003). In this context the section of the profile from Lake Kwiecko dated at around 16,000 years ${ }^{14} \mathrm{C} \mathrm{BP}$, with a 
Table 1. Results of AMS radiocarbon dating of various types of material from Lake Kwiecko sediments, $(p e=$ pollen extract, wood = terrestrial plant wood fragment, Call = Calliergon stramineum leaves, $m o=$ mosses fragments, Drep = Drepanocladus aduncus leaves).

\begin{tabular}{|c|c|c|c|c|c|}
\hline \multirow[t]{2}{*}{$\begin{array}{l}\text { Sample name / } \\
\text { material / depth }\end{array}$} & \multirow[t]{2}{*}{ Laboratory code } & \multirow[t]{2}{*}{$\begin{array}{l}\text { Radiocarbon age } \\
\text { (yr BP) }\end{array}$} & \multicolumn{2}{|c|}{$\begin{array}{c}\text { Cal age BP } \\
\text { Conf. intervals }\end{array}$} & \multirow[t]{2}{*}{$\begin{array}{l}\text { Remark of the } \\
\text { Laboratory }\end{array}$} \\
\hline & & & $68.3 \%$ (1 sigma) & $95.4 \%$ (2 sigma) & \\
\hline Lake Kwiecko/pe/175cm & Poz-2298 & $1760 \pm 30$ & 1619-1674 & $1567-1739$ & $0.5 \mathrm{mgC}$ \\
\hline Lake Kwiecko/pe/365cm & Poz-2299 & $1940 \pm 30$ & $1865-1926$ & $1822-1949$ & \\
\hline Lake Kwiecko/pe/555cm & Poz-2300 & $2840 \pm 35$ & 2919-2996 & 2863-3064 & \\
\hline Lake Kwiecko/pe/805cm & Poz-2301 & $3810 \pm 30$ & $4151-4240$ & $4137-4295$ & \\
\hline Lake Kwiecko/pe/1255cm & Poz-2303 & $5630 \pm 40$ & $6393-6452$ & $6314-6487$ & \\
\hline Lake Kwiecko/pe/1465cm & Poz-2297 & $6010 \pm 40$ & $6791-6897$ & $6745-6948$ & $0.45 \mathrm{mgC}$ \\
\hline Lake Kwiecko/pe/1930cm & Poz-2304 & $7860 \pm 120$ & $8543-8787$ & $8429-8997$ & $0.1 \mathrm{mgC}$ \\
\hline Lake Kwiecko/pe/2096cm & Poz-2305 & $9500 \pm 90$ & $10656-10832$ & $10561-11143$ & $0.2 \mathrm{mgC}$ \\
\hline Lake Kwiecko/wood/2123cm & Poz-203 & $9480 \pm 50$ & $10654-10787$ & $10582-10833$ & \\
\hline Lake Kwiecko/wood/2131cm & Poz-206 & $10220 \pm 50$ & $11953-12050$ & $11751-12130$ & \\
\hline Lake Kwiecko/pe/2185cm & Poz-2307 & $11900 \pm 200$ & $13535-13979$ & $13293-14203$ & $0.1 \mathrm{mgC}$ \\
\hline Lake Kwiecko/pe/2215cm & Poz-2308 & $12050 \pm 380$ & $13458-14491$ & $13210-15099$ & $0.05 \mathrm{mgC}$ \\
\hline Lake Kwiecko/Call/2223-2225cm & Poz-304 & $16270 \pm 230$ & $19168-19580$ & $18997-19870$ & $0.2 \mathrm{mgC}$ \\
\hline Lake Kwiecko/mo/2223-2225cm & Poz-211 & $16420 \pm 100$ & 19466-19588 & 19411-19844 & \\
\hline Lake Kwiecko/Drep/2223-2225cm & Poz-264 & $16490 \pm 170$ & $19495-19816$ & 19307-19998 & \\
\hline
\end{tabular}

high proportion of trees (AP min. 92\%-99.5\%) such as Pinus (min. 55\% - max 75\%) and Betula (min. 40\%, max $65 \%)$ as well as Corylus (max $20 \%$ ) does not contribute in terms of its pollen composition to the picture presented here of the vegetation present in the upper Plenivistulian.

Neither should this section of the palynological profile from Kwiecko under discussion be associated with the late Vistulian. Despite an improvement in climate, the forest communities were not as unbroken as can be inferred from the diagram from Lake Kwiecko, where the component of herbaceous vegetation varies from $0.5 \%$ to a maximum of $8 \%$ in the Preboreal. To compare, in the pollen diagram from Lake Mukrz the proportions of NAP vary from around $7 \%$ to $28 \%$ (Noryśkiewicz, 2006). According to isopollen maps for Poland, proportions of Corylus as high as in the sediments from Lake Kwiecko were not recorded at other sites of the latter part of the late glacial (Miotk-Szpiganowicz et al., 2004). A characteristic feature of open communities of the Late Glacial is a generally high proportion of heliophytes such as Helianthemum, Artemisia or Chenopodiaceae. In the discussed section of the profile from lake Kwiecko no Helianthemum pollen grains were recorded; the Artemisia curve remains at a level of $1 \%$, much as sediments from Lake Gościąż, and single grains of Chenopodiaceae were recorded (Lake Gościąż - discontinuous curve) (RalskaJasiewiczowa et al., 1998).

That the conditions of climate were relatively favorable during the sedimentation of the section under discussion may be proved by the fact of recording Typha latifolia grains in the sediment from Lake Kwiecko, which required the mean July temperature to be no lower than $13-15^{\circ} \mathrm{C}$, and Myriophyllum verticilatum - average July temperature required is $10-13^{\circ} \mathrm{C}$ (Isarin and Bohncke 1999; Weber and Nooden, 1974), as well as the presence of high percentages of Tetraedron minimum (RalskaJasiewiczowa et al., 2003).

\section{Loss on ignition}

The content of carbonates and organic carbon obtained during analysis indicates its variability throughout the profile. However, their concentration was found to be highest, reaching $40 \%$, at the bottom of the profile which is associated with the Preboreal, from where the moss remains subjected to the AMS radiocarbon dating method were taken.

\section{Radiocarbon dating}

In the whole profile from Lake Kwiecko, 15 AMS radiocarbon dates were made. Within the section associated with the Preboreal, 8 samples were dated: three of moss remains (Drepanocladus aduncus, Calliergon stramineum and one unidentified moss fragment), three samples of pollen concentrates, and two of unidentified plant remains.

The dated moss remains taken from the same level $(22.23-22.25 \mathrm{~m})$ gave results of $16,490 \pm 170,16,420 \pm 100$ and $16,270 \pm 230{ }^{14} \mathrm{C}$ BP Poz-264, Poz-211, Poz-304). In accordance with the palynological dating adopted, the beginning of sedimentation at the bottom of Lake Kwiecko should be associated with the beginning of the Holocene, i.e. with a date of around $10,000{ }^{14} \mathrm{C}$ BP. Accordingly, the ${ }^{14} \mathrm{C}$ results obtained should be considered to be too old over 6000 years. Grains of pollen isolated from layers found $10 \mathrm{~cm}$ and $60 \mathrm{~cm}$ above the bottom of the rock layer gave a date of $12,050 \pm 380$ and $11,900 \pm 200{ }^{14} \mathrm{C}$ BP (Poz-2308, Poz-2307), while the plant remains from a depth of $21.31 \mathrm{~m}$ and $21.23 \mathrm{~m}$ gave dates of $10,220 \pm 50$ and $9480 \pm 50{ }^{14} \mathrm{C} \mathrm{BP}$, respectively. Here the age differences between the expected and obtained dates are smaller (Fig. 3).

\section{Contemporary material}

The two species of moss identified at the bottom of the rock layers, Drepanocladus aduncus and Calliergon stramineum, have similar requirements in terms of habitat. They often occur at localities in which there is a high 


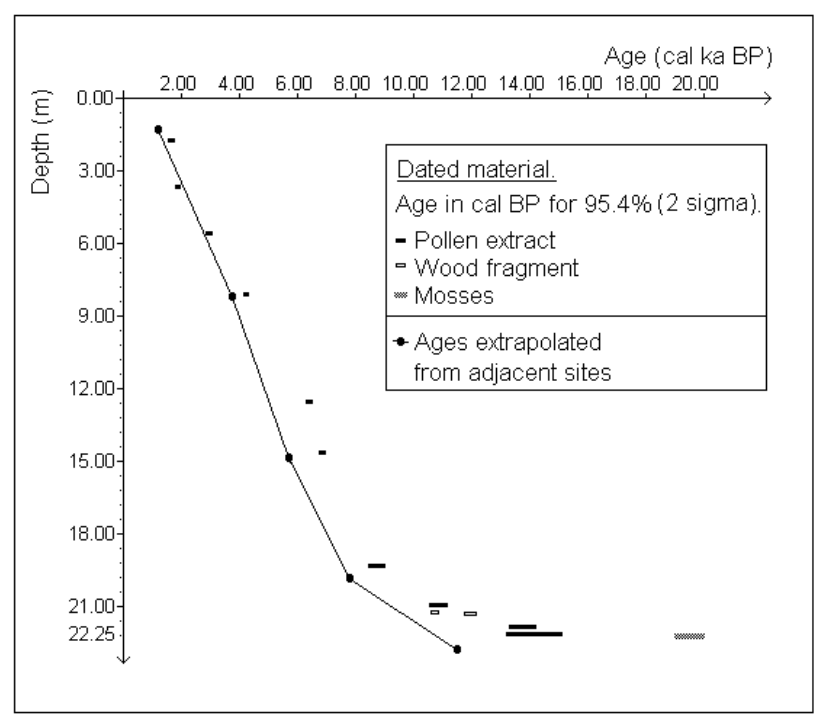

Fig. 3. Graph presenting the results of AMS radiocarbon dating of various types of material from the sediments of Lake Kwiecko and a curve presenting the age/depth relationship plotted on the basis of correlating the palynological chrononology of sediments from Lake Kwiecko with data from other sites, namely Lake Gacno Wielkie (Hjelmroos-Ericsson, 1981), Lake Mały Suszek (Miotk-Szpiganowicz, 1989 and 1992), Lake Gościąż (Ralska-Jasiewiczowa et al., 1998).

level of ground moisture. Calliergon stramineum is most frequently recorded in areas of springs and wet meadows while Drepanocladus aduncus is also found in fens, wet meadows, muds, and the edges of lakes, ponds, and watercourses (Szafran, 1961). They are often present in an environment characterized by very high $\mathrm{CaCO}_{3}$ content (Vitt et al., 1993).

Photosynthetic activity was measured using a fresh specimen of Drepanocladus aduncus collected in the field and immersed in the aqueous reaction mixture. These measurements showed both the $\mathrm{pH}$ of the bathing solution to rise above ca. 1 unit, and the release of oxygen (Fig. 4), thus clearly demonstrating high photosynthetic activity of the moss. However, these results show also that source of carbon for sugar synthesis in Drepanocladus aduncus is not bicarbonate but mostly carbon dioxide (Bain and Proctor, 1980; Mott and Jackson, 1982; MacDonald et al., 1987). If the $\mathrm{HCO}_{3}{ }^{-}$ion were being used to produce sugar photosynthetically, the result would be an accumulation of $\left(\mathrm{H}_{3} \mathrm{O}^{+}\right)$ions and acidification of the environment as evidenced by a fall in the $\mathrm{pH}$ of the solution.

\section{Discussion}

The results obtained show inconsistencies between palynological data and radiocarbon ages obtained from mosses. The palynological picture is typical of the beginning of the Holocene, while the results of moss radiocarbon dating are aged considerably.

Problems with moss radiocarbon dating have been known for many years. It has been demonstrated that their remains can produce ${ }^{14} \mathrm{C}$ ages which are older than those for terrestrial macrofossils from the same or younger stratigraphic level. Some interesting results obtained by MacDonald et al. (1987) showed that radiocar-

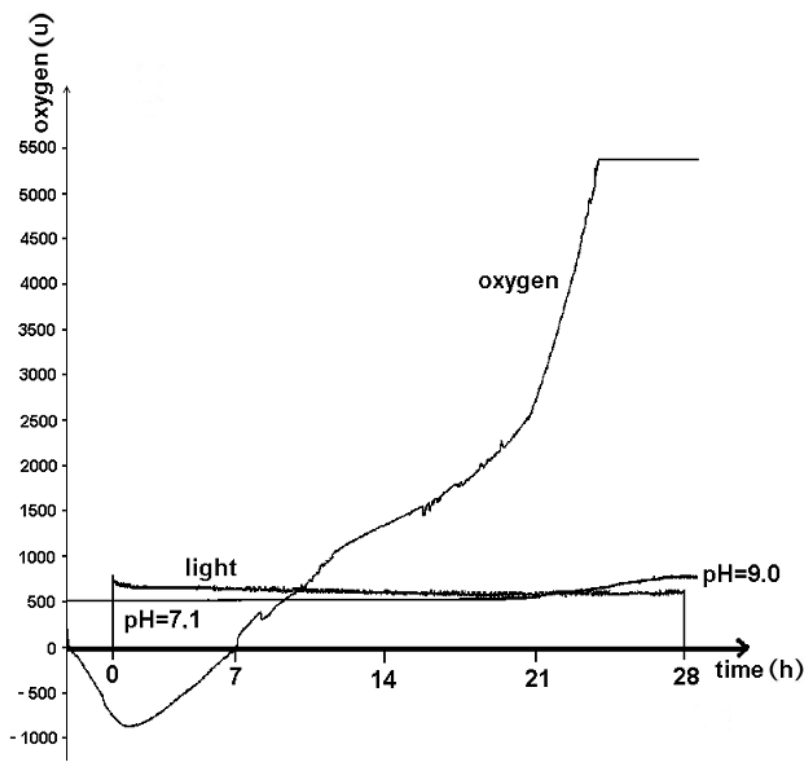

Fig. 4. Graph presenting the results of measuring the photosynthetic activity of Drepanocladus aduncus (description in text).

bon dating of living samples of Drepanocladus crassicostatus collected in 1996 and 1985 provided radiocarbon ages significantly older than modern and contained less than $85 \%$ of modern ${ }^{14} \mathrm{C}$. This result suggests that the living plants had access to ${ }^{14} \mathrm{C}$-deficient carbon which they were able to assimilate during photosynthesis, so that the aforementioned is not simply the result of postmortem processes.

As was demonstrated in our study of the moss Drepanocladus aduncus, it has photosynthetic activity while submerged in the water but cannot incorporate $\mathrm{HCO}_{3}{ }^{-}$ ions. The main source of carbon for photosynthesis reactions is $\mathrm{CO}_{2}$, but it is well known that in water $\mathrm{CO}_{2}$ can be generated from $\mathrm{HCO}_{3}{ }^{-}$, particularly when depletion of $\mathrm{CO}_{2}$ is observed. Bain and Proctor (1980) suggested that mosses can draw upon the reservoir of $\mathrm{CO}_{2}$ in $\mathrm{HCO}_{3}{ }^{-}$if $\mathrm{pH}$ remains below the free- $\mathrm{CO}_{2}$ compensation point. $\mathrm{CO}_{2}$ can be also generated from $\mathrm{HCO}_{3}{ }^{-}$in the groundwater as it enters the lake if the $\mathrm{pH}$ of the $\mathrm{HCO}_{3}{ }^{-}$-rich groundwater is higher than that of the lake. It is also known that $\mathrm{HCO}_{3}{ }^{-}$ ions can arise in water both as a result of the interaction of atmospheric $\mathrm{CO}_{2}$ with water and as an effect of water contact with carbonate rocks in accordance with the following equilibrium:

$$
\mathrm{CO}_{2}+\mathrm{H}_{2} \mathrm{O}+\mathrm{CaCO}_{3}=\mathrm{Ca}\left(\mathrm{HCO}_{3}\right)_{2}
$$

$\mathrm{Ca}\left(\mathrm{HCO}_{3}\right)_{2}$ is dissolved in water and may release $\mathrm{CO}_{2}$ which can be used in photosynthesis:

$$
\mathrm{Ca}\left(\mathrm{HCO}_{3}\right)_{2}=\mathrm{Ca}^{2+}+\mathrm{HCO}_{3}^{-}
$$

and:

$$
\mathrm{HCO}_{3}^{-}+\mathrm{H}_{3} \mathrm{O}^{+}=\mathrm{H}_{2} \mathrm{CO}_{3}+\mathrm{H}_{2} \mathrm{O}
$$

and:

$$
\mathrm{H}_{2} \mathrm{CO}_{3}=\mathrm{H}_{2} \mathrm{O}+\mathrm{CO}_{2}^{\uparrow}
$$


If the limestone rocks contain ${ }^{14} \mathrm{C}$-deficient carbon, the $\mathrm{CO}_{2}$ released from these rocks will likewise be deficient in ${ }^{14} \mathrm{C}$. If the $\mathrm{CO}_{2}$ which contains ${ }^{14} \mathrm{C}$-deficient carbon is assimilated by plants and incorporated in sugar synthesis in their cells, the ${ }^{12} \mathrm{C} /{ }^{14} \mathrm{C}$ equilibrium in the plant tissues will be significantly disturbed. The release of the $\mathrm{CO}_{2}$ from ${ }^{14} \mathrm{C}$-deficient $\mathrm{HCO}_{3}{ }^{-}$is the main reason for the presence of ${ }^{14} \mathrm{C}$-deficient carbon in Lake Kwiecko.

The high level of carbonates probably also affected the results of dating pollen concentrates isolated from the sediment. Carbonates are readily deposited on the porous surfaces of pollen, if present in their vicinity in large amounts (Kilian et al., 2002). Perhaps the same phenomenon is also responsible for the aged results obtained for wood fragments (Poz-206, Poz-203) and had an additional effect on the results of dating moss remains. Another difficulty which must have affected the results of dating pollen concentrates taken from the bottom layer of the profile was that of obtaining suitably clean samples. They contained non-pollen contaminants such as the microfragments of unidentified plant tissues, possibly including those of mosses.

\section{CONCLUSION}

This paper presents the results of pollen analysis for the bottom sediments of Lake Kwiecko, the results of AMS radiocarbon dating, carbonate content in sediment, and also results that demonstrate the photosynthetic activity of Drepanocladus aduncus under conditions of being submerged in solution. The palynological data obtained clearly indicate the beginning of the Holocene as the period during which the accumulation of sediments begins in the lake. The proportion of $\mathrm{CaCO}_{3}$ in the sediment was high, reaching $40 \%$ at the bottom of the profile. The results of AMS radiocarbon dating of moss remains seem to be over 6000 years too old in relation to the palynological chronology. The most likely reason for such old dates having been obtained is the incorporation into the moss tissues of carbon atoms from dissolved old carbonate rocks during the photosynthesis that took place during their periodic flooding. Doubtless, the possible carbonate deposition on the surface of the dated material could also have affected the dating, as could the presence of other molecules. While radiocarbon dating is without doubt one of the most important tools in paleoecological research, the results obtained must be subject to critical evaluation and correlation with data obtained using other research methods.

\section{REFERENCES}

Allen ED and Spence DH, 1981. The differential ability of aquatic plants to utilize the inorganic carbon supply in fresh waters. New Phytologist 87(2): 269-283, DOI $10.1111 / \mathrm{j} .1469-$ 8137.1981.tb03198.x.

Bain JT and Proctor MC, 1980. The requirement of aquatic bryophytes for free $\mathrm{CO}_{2}$ as an inorganic carbon source: some experimental evidence. New Phytologist 86(4): 393-400, DOI 10.1111/j.14698137.1980.tb01680.x.

Balwierz Z, 2003. Roślinność vistulianu w Polsce środkowej (The Vistulian vegetation of central Poland). Botanical Guidebooks 26: 217-232 (in Polish).
Berglund BE and Ralska-Jasiewiczowa M, 1986. Pollen analysis and pollen diagrams. In: Berglund BE, ed., Handbook of Holocene palaeoecology and palaeohydrology. Chichester, John Wiley \& Sons: 455-484.

Brown TA, Nelson DE, Mathewes RW, Vogel JS and Southon JR, 1989. Radiocarbon dating of pollen by Accelerator Mass Spectrometry. Quaternary Research 32(2): 205-212, DOI 10.1016/0033-5894(89)90076-8.

Dean WE Jr., 1974. Determination of carbonate and organic matter in calcareous sediments and sedimentary rocks by loss on ignition: Comparison with other methods. Journal of Sedimentary Petrology 44(1): 241-248.

Hjelmroos-Ericsson M, 1981. Holocene development of Lake Wielkie Gacno area, northwestern Poland. University of Lund, Department of Quaternary Geology, Thesis 10: $101 \mathrm{pp}$.

Isarin FB and Bohncke SP, 1999. Mean July temperatures during the Younger Dryas in Northwestern and Central Europe as inferred from climate indicator plant species. Quaternary Research 51(2): 158-173, DOI 10.1006/qres.1998.2023.

Kilian MR, van der Plicht J, van Geel B and Goslar T, 2002. Problematic ${ }^{14} \mathrm{C}$-AMS dates of pollen concentrates from Lake Gościąż (Poland). Quaternary International 88(1): 21-26, DOI 10.1016/S1040-6182(01)00070-2.

Kondracki J, 2002. Geografia regionalna Polski. Wydawnictwo Naukowe PWN: 468 pp.

MacDonald GM, Beukens RP, Kieser WE and Vitt DH, 1987. Comparative radiocarbon dating of terrestrial plant macrofossils and aquatic moss from the "ice corridor" of western Canada. Geology 15(9): $\quad 837-840, \quad$ DOI $10.1130 / 0091-$ 7613(1987) $15<837$ :CRDOTP $>2.0 . \mathrm{CO} ; 2$.

Mangerud J, Andersen ST, Berglund BE and Donner JJ, 1974. Quaternary stratigraphy of Norden, a proposal for terminology and classification. Boreas 3(3): 109-126, DOI $10.1111 / \mathrm{j} .1502-$ 3885.1974.tb00669.x.

Mamakowa K, 2003. Plejstocen (Pleistocene). In: Dybova-Jachowicz S and Sadowska A, eds. Palinologia (Palynology). Wydawnictwo Instytutu Botaniki PAN, Kraków: 235-266 (in Polish).

Mamakowa K and Starkel L, 1977. Stratigraphy of the Late Glacial and Early Holocene alluvia at Podgrodzie on the Wisłoka-River (SE Poland). Studia Geomorphologica Carpatho-Balcanica 11. 101110.

Miotk-Szpiganowicz G, 1989. Type Region P-s: Bory Tucholskie. Acta Palaeobotanica 29(2): 81-84.

Miotk-Szpiganowicz G, 1992. The history of the vegetation of Bory Tucholskie and the role of man in the light of palynological investigations. Acta Palaeobotanica 32(1): 39-122.

Miotk-Szpiganowicz G, Zachowicz J, Ralska-Jasiewiczowa M and Nalepka D, 2004. Corylus avellana L. - Hazel. In: RalskaJasiewiczowa M, Latałowa M, Wasylikowa K, Tobolski K, Madeyska E, Wright HE and Turner Ch, eds., Late Glacial and Holocene history of vegetation in Poland based on isopollen maps: 7987.

Mott RJ, Jackson Jr. LE, 1982. An 18,000 year palynological record from the southern Alberta segment of the classical Wisconsinian "ice-free corridor". Canadian Journal of Earth Sciences 12: 273288, DOI 10.1139/e75-024.

Nakagawa T, Brugiapaglia E, Digerfeldt G, Reille M, Beaulieu J and Yasuda Y, 1998. Dense-media separation as a more efficient pollen extraction method for use with organic sediment/deposit samples: comparison with the conventional method. Boreas 27(1): 1524, DOI 10.1111/j.1502-3885.1998.tb00863.x.

Noryśkiewicz AM, 2006. Historia cisa w okolicy Wierzchlasu w świetle analizy pyłkowej. (The history of the yew in the Wierzchlas in light of palynological research). Torun: Wydawnictwo Uniwersytetu Mikołaja Kopernika; Gruczno: Towarzystwo Przyjaciół Dolnej Wisły: 86 pp (in Polish).

Ralska-Jasiewiczowa M, 1980. Late-glacial and Holocene vegetation of the Bieszczady Mts (Polish Eastern Carpathians). WarszawaKraków, PWN: 202 pp.

Ralska-Jasiewiczowa M, van Geel B and Demske D, 1998. Holocene regional vegetation history recorded in the Lake Gościąż sediments. In: Ralska-Jasiewiczowa M, Goslar T, Madeyska T and Starkel L, eds. Lake Gościąż, Central Poland. A monographic study. Part 1. Kraków, W. Szafer Institute of Botany Polish Academy of Sciences: 202-219.

Ralska-Jasiewiczowa M, Goslar T, Różański K, Wacnik A, Czernik J and Chróst L, 2003. Very fast environmental changes at the Pleis- 
tocene/Holocene boundary, recorded in laminated sediments of Lake Gościąż, Poland. Palaeography, Palaeoclimatology, Palaeoecology 193(2): 225-247, DOI 10.1016/S00310182(03)00227-X

Reimer PJ, Baillie MGL, Bard E, Bayliss A, Beck JW, Bertrand CJH, Blackwell PG, BuckCE, Burr GS, Cutler KB, Damon PE, Edwards RL, Fairbanks RG, Friedrich M, Guilderson TP, Hogg AG, Hughen KA, Kromer B, McCormac FG, Manning SW, Ramsey CB, Reimer RW, Remmele S, Southon JR, Stuiver M, Talamo S, Taylor FW, van der Plicht J and Weyhenmeyer CE, 2004. IntCal04 Terrestrial radiocarbon age calibration, $26-0 \mathrm{ka}$ BP. Radiocarbon 46: 1029-1058.

Stockmarr J, 1971. Tablets with spores used in absolute pollen analysis. Pollen et Spores 13(4): 615-621.

Stuiver M and Reimer PJ, 1993. Extended 14C data base and revised CALIB 3.0 14C age calibration program. Radiocarbon 35: 215230.

Szafran B, 1961. Mchy (Musci). Vol. II. PWN: 405 pp.

Tobolski K, 1991. Biostratygrafia i paleoekologia interglacjału eemskiego i zlodowacenia Wisły regionu konińskiego (Biostratygra phy and palaeoecology of the Eemian Interglacial and the Vistulian Glaciation of the Konin region). In: Stankowski W, ed. Przemiany środowiska geograficznego obszaru Konin-Turek (Changes of geographical environment in Konin-Turek area). UAM Poznań: 45-87 (in Polish).

Vitt DH, van Wirdum G, Halsey L Zoltaj S, 1993. The effects of water chemistry on the growth of Scorpidium scorpioides in Canada and The Netherlands. The Bryologist 96(1): 106-111, DOI $10.2307 / 3243326$.

Walanus A and Nalepka D, 1999. POLPAL programs for counting pollen grains, diagrams plotting and numerical analysis. In: Stuchlik L, ed., Proceedings of the Fifth European Palaeobotanical and Palynological Conference June 26-30. 1998, Kraków. Acta Palaeobotanica. Supplementum 2: 659-661.

Weber JA and Nooden LD, 1974. Turion formation and germination in Myriophyllum verticillatum; phenology and its interpretation. Michigan Botanist 11: 115-121.

Więckowski K, 1970. New type of lightweight piston core sampler. Bulletin de l'Academie Polonaise des Sciences, Geol.-Geogr. 18: 57-62. 